\title{
Survey of Learning Analytics based on Purpose and Techniques for Improving Student Performance
}

\author{
Suchithra R, Ph.D \\ Department of Computer \\ Science, Jain University \\ Bengaluru
}

\author{
V.Vaidhehi \\ Department of Computer \\ Science, Christ University \\ Bengaluru
}

\author{
Nithya Easwaran lyer \\ Department of Computer \\ Science, Sri Vani International \\ School, Bengaluru
}

\begin{abstract}
I Learning Analytics is a process to analyze the learners which improves the educational performance. Learning Analytics also helps the higher educational institutions to improve the educational practices and techniques. This paper provides a detailed survey of the current research activities conducted in the education system. The review of Learning Analytics is based on some of existing Learning Analytics applications, purpose of the Learning Analytics in the education system and the type of students. The review based on various tools, techniques and data collection methods used to implement the Learning analytics is discussed in this paper.
\end{abstract}

\section{Keywords}

Learning Analytics, tools, techniques

\section{INTRODUCTION}

Course selection is essential for every student to decide the career. Demand rate for the courses also vary from one academic year to the other. Therefore, it is important for the student to choose the best courses based on some of the factors like marks, personal interests, peer pressure, parental pressure, job opportunity etc. Success of the student mainly depends on the interest of the student towards the course. In India, the percentage of the students after the pre - university or Higher Secondary School education continuing the degree level education is less. For every academic year, maintaining the school records and mapping the student after the HSC or PU is very difficult. It is observed that most of the problems of learners are to a specific geographical region, specific course, online courses and distant learning courses.

Higher education institutions should understand the learners' requirements in such a way that a manufacturing company understands the customer needs. Traditionally, questionnaire and survey methods were adopted to identify the strategy of teaching - learning environments. Every student who access the digital learning resource, leave a trace. This trace is so large and it could be collected and used as Big Data. Recently, due to the advancements in software industry, it is possible to have different processing areas on educational data like Educational data mining, Academic Analytics, Learning Analytics, Networked learning, Technology enhanced learning, Computer-supported collaborative learning and Mobile learning.

The main purpose of Learning Analytics is to improve the performance of learners. Also, the environment of learning in which the learner undergoes is enhanced which will ultimately result in a quality education. Learning Analytics helps educator/ teacher to understand the students. Learning capabilities can be improved for the learners.

\section{LEARNING ANALYTICS}

Software analytics has taken a different route in all fields. Traditionally, education data was kept in files and records.
Data generated by the educational system is huge. Then, the storage systems were introduced to store the educational data. The first stage of revolution happened in education is when learning management system (LMS) got introduced. The second stage of revolution in education is due to education enterprise system. The third stage is learning analytics.

Learning Analytics is about the collection, analysis of data about the learners. It is an emerging field in research which uses data analysis on every tier of educational system. The analysis could be

- About the performance of learners through assessment

- About the participation of learners in traditional class rooms

- About the participation of learners in online learning rooms

- Participation in discussions

- About the learners skill which helps the teacher

- Personalized suggestions

- Decision making (Enrollments for universities)

- $\quad$ Success factors of students

- $\quad$ Feedback system

- Pedagogy

Academic analytics is for the institution level. Institution can use academic analysis to know the success of the students. It can also be used to get the attention of public. Report of the analysis can be used for the publicity of the institution.

There are two types of analytics that is possible on an educational data. Course level analytics is based on the analysis on the course. Both the learners and educators are benefitted by this type of analysis. Aggregate analytics is based on aggregate analysis which involves predictive modeling and the pattern of success or failure of the course.

This paper is organized as review of various Learning Analytics Applications used in the university education system. The purpose of the Learning Analytics is reviewed. Then the different type of students involved in education system is also considered. Various tools, techniques and data collection methods used to implement the Learning analytics is discussed.

\section{LITERATURE SURVEY}

The major research work carried in the field of course advisory systems is multi - discipline in nature which includes education, psychology and computer science. Also, the research activities performed in education using Learning 
Analytics are customized to need of the people in the society. This shows that needs are different for different people like Rural/urban. The existing advisory systems in this field are designed

- To improve the performance of students

- To be used after joining a particular course

\section{LEARNING ANALYTICS APPLICATIONS}

The literature shows the different learning analytics applications used by different universities across the globe. To satisfy the various needs of the University, Learning Analytics applications are developed and used. These applications are developed as standalone or web based applications. Web based applications help the student to monitor the progress and to devise the academic plan. Various web based Learning Analytics applications used by universities are listed in table 1.

Table 1: Learning Analytics applications

\begin{tabular}{|c|c|c|}
\hline Slno & $\begin{array}{c}\text { Learning } \\
\text { analytics } \\
\text { applications }\end{array}$ & University \\
\hline 1 & Jpoll & Griffith University \\
\hline 2 & Moodog & University of California \\
\hline 3 & Equella & University of Wollongong \\
\hline 4 & E2coach & University of Michigan \\
\hline 5 & Signals & Purdue University \\
\hline
\end{tabular}

\section{TYPE OF STUDENTS}

Learning Analytics system is designed for target people like school students, university students, engineering branch and online students. The major research work is towards the university students and their performance. Also, various research activities are performed towards virtual class room (online students). Table 2 indicates the literature work on various kinds of students.

Table 2: Type of students

\begin{tabular}{|c|c|c|}
\hline Slno & $\begin{array}{c}\text { Type of } \\
\text { students }\end{array}$ & Literature \\
\hline 1 & $\begin{array}{c}\text { Engineering } \\
\text { students }\end{array}$ & {$[1],[28]$} \\
\hline 2 & $\begin{array}{c}\text { University } \\
\text { students }\end{array}$ & $\begin{array}{c}{[2],[4],[5],[10],[12],[13],} \\
{[14],[15],[16]}\end{array}$ \\
\hline 3 & $\begin{array}{c}\text { Virtual class } \\
\text { room/ } \\
\text { online } \\
\text { students } \\
4\end{array}$ & $\begin{array}{r}{[4],[6],[7],[8],[18],[21],[22]} \\
,[25],[27]\end{array}$ \\
& $\begin{array}{c}\text { School } \\
\text { students }\end{array}$ & {$[9]$} \\
\hline
\end{tabular}

\section{TOOLS}

The various tools used in learning analytics include SPSS, Weka, Rapid Miner, Web based tools and visualization tool. Table 3 lists the tools predominantly used for analysis in the literature.

Table 3: Tools

\begin{tabular}{|c|c|c|}
\hline Slno & tools & Literature \\
\hline 1 & SPSS & {$[10]$} \\
\hline 2 & Weka & {$[9]$} \\
\hline 3 & Rapidminer & {$[13]$} \\
\hline 4 & Web based tools & {$[12],[23]$} \\
\hline 5 & Gephi visualization tool & {$[3]$} \\
\hline
\end{tabular}

\section{PURPOSE OF LEARNING ANALYTICS}

It is evident from the literature that the purpose of learning analytics to the education system is varied in nature. The learning Analytics aims at the curriculum design, predicting the students performance, improving the teaching learning environment, decision support system for Higher Education Institutions, personalized approach to individual students, online and other learning modes including mobile, subject wise teaching and learning, subjects which has practical and evaluation process in the education system. Students' studying the online courses using different devices like mobile phones and other gadgets is also discussed in the literature. Tracking the student activities in the lab oriented subjects like Java programming is also discussed. Monitoring the students undergoing online courses, their emotions, responses, participation is considered in the recommendation systems. Table 4 summarizes the purpose of Learning Analytics.

Table 4: Purpsose of Learning Analytics

\begin{tabular}{|c|c|c|}
\hline SIno & Purpose & Literature \\
\hline 1 & $\begin{array}{l}\text { Design curriculum based } \\
\text { on industry requirements }\end{array}$ & {$[1]$} \\
\hline 2 & $\begin{array}{l}\text { Improve/ predict the } \\
\text { performance of the } \\
\text { students }\end{array}$ & $\begin{array}{c}{[2],[8],[9],[14],[18],} \\
{[25],[28]}\end{array}$ \\
\hline 3 & HEI & [3], [17] \\
\hline 4 & $\begin{array}{l}\text { Enhance the teaching } \\
\text { learning environment }\end{array}$ & {$[4],[5],[19]$} \\
\hline 5 & $\begin{array}{c}\text { Mobile learners and } \\
\text { teachers }\end{array}$ & {$[4],[6],[15],[21]$} \\
\hline 6 & Personalized approach & [7] \\
\hline 7 & $\begin{array}{c}\text { To know about the type } \\
\text { of interactions in an } \\
\text { online course }\end{array}$ & {$[24]$} \\
\hline 8 & Identifying the Dropouts & [9] \\
\hline 9 & $\begin{array}{c}\text { Subjectwise --- } \\
\text { SE/Java/journal } \\
\text { publication }\end{array}$ & {$[4],[5],[10],[16],[20]$} \\
\hline 10 & $\begin{array}{l}\text { Evaluation assignment / } \\
\text { practical subjects/ self }\end{array}$ & {$[12],[13],[15],[22]$} \\
\hline
\end{tabular}




\begin{tabular}{|c|c|c|}
\hline & evaluation & \\
\hline 11 & Recommendations & {$[11],[15],[18],[24],[25]$} \\
\hline
\end{tabular}

\section{TECHNIQUES}

Literature shows the usage of different technologies for the design Learning Analytics system. The technologies include Artificial Intelligence, Data Mining, Adaptive learning, Inquiry and problem based learning, Predictive modeling, Clustering, Pattern mining, Relationship mining, Sequential analysis ,Performance prediction, Bayesian knowledge tracing and Sequencing the tasks.

Neural networks and machine language techniques are used to predict the student performance. Data Mining techniques like linear regression, support vector regression, regression trees, clustering and clustering methods are used to evaluate the student performance. Some of the statistical methods like Euclidean Euclidean squared, Pearson Spearman and BrayCurtis methods are used to evaluate the student performance. Data mining techniques are also used to construct recommendation systems based on emotions in an online learing environment. Mobile technology and Internet of things plays a vital role in virtual class rooms. Visualization techniques are widely used in representing educational data. Table 5 lists the various techniques used.

Table 5: Techniques used

\begin{tabular}{|c|c|c|}
\hline SIno & Technology & Literature \\
\hline \multirow[t]{3}{*}{1} & $\begin{array}{l}\text { Using Neural networks And } \\
\text { decision trees for prediction }\end{array}$ & [28] \\
\hline & $\begin{array}{l}\text { Machine Language techniques } \\
\text { for performance prediction } \\
\text { Bayesian Knowledge Tracing } \\
\text { (BKT), Performance Factors } \\
\text { Analysis ,Matrix Factorization } \\
\text { (MF) }\end{array}$ & {$[25]$} \\
\hline & $\begin{array}{c}\text { Agent based classication } \\
\text { system }\end{array}$ & {$[8]$} \\
\hline \multirow[t]{6}{*}{2} & $\begin{array}{l}\text { Comparison of Kmeans and } \\
\text { PSO clustering algorithms }\end{array}$ & {$[16]$} \\
\hline & $\begin{array}{l}\text { DM techniques linear } \\
\text { regression, support vector } \\
\text { regression and regression tree }\end{array}$ & [13] \\
\hline & $\begin{array}{l}\text { Classification algorithms } \\
\text { based on rules and decision } \\
\text { trees }\end{array}$ & [9], [14] \\
\hline & $\begin{array}{l}\text { Agent based classification } \\
\text { methods }\end{array}$ & [8] \\
\hline & $\begin{array}{c}\text { Statistical methods Euclidean } \\
\text { Euclidean squared, Pearson } \\
\text { Spearman and Bray-Curtis } \\
\text { methods. }\end{array}$ & {$[22]$} \\
\hline & Neuro Fuzzy system & {$[2]$} \\
\hline 3 & Statistical methods & [1] \\
\hline 4 & Statistical methods & $\begin{array}{c}{[4],[5],} \\
{[10],[12]}\end{array}$ \\
\hline 5 & Java based prototype---gephi & [3] \\
\hline
\end{tabular}

\begin{tabular}{|c|c|c|}
\hline \multirow{2}{*}{6} & $\begin{array}{c}\text { Line connectors; Merged } \\
\text { Bezier curve connectors }\end{array}$ & {$[26]$} \\
\cline { 2 - 3 } & IOT & {$[4]$} \\
\hline 7 & Mobile technology & {$[6],[15]$} \\
\hline 8 & Social Network Analysis & {$[7]$} \\
\cline { 2 - 3 } & $\begin{array}{c}\text { Reinforcement Learning, MF, } \\
\text { and BKT }\end{array}$ & {$[27]$} \\
\hline \multirow{2}{*}{9} & collaborative filtering & {$[19]$} \\
\cline { 2 - 3 } & $\begin{array}{c}\text { Based on emotions---DM } \\
\text { techniques }\end{array}$ & {$[24]$} \\
\hline
\end{tabular}

\section{DATA COLLECTION METHODS}

The different data collection methods discussed widely throughout the various literature include the traditional questionnaire being prepared and circulated and collecting data based on the responses from the various people. The data collection method is to use the existing learning management system in the higher education institution. Also Log maintained in the LMS system will assist the analyzer and researcher on various parameters. Overall, the various research activities include the combination of these three ways of collecting the data.

Table 6 :Data collection methods

\begin{tabular}{|c|c|}
\hline Slno & Methods \\
\hline 1 & Questionnaire \\
\hline 2 & Learning Management System \\
\hline 3 & Log details \\
\hline
\end{tabular}

The various issues concerned with data collection is due to the nature of data like, Structured data, unstructured data and semi structured data. Structured data refers to the data from Web analytics, data warehouses, and other data-management tools. Unstructured data refers to the data from documents, emails, answers, responses, and other online discussions. Semi - structured data is a combination of structured and unstructured data.

\section{CONCLUSION}

The study shows that the usage of learning analytics is very limited to Higher education institutions in India. In many cases, Higher education institutions in India are not aware of the courses needed by the students. Knowledge from the data mining should be brought out to higher education institutions so that courses could be structured based on the need. The literature review shows that the various research activities are concerned mainly on students after joining into a particular course. This proves to be detrimental if the student has not selected a course properly.

Education is the basic need for the developing countries like India. To increase the number of students continuing higher education, the future research work is towards the design of a system for students to choose courses in the Indian universities using Learning Analytics. An efficient course advisory system can enhance the student performance. Such course advisory system minimizes the drop outs in higher education due to improper course selection. Course advisory systems also help the higher education institutions to plan the 
education system by knowing the demand for each course in an efficient way. Course advisory systems assist the teachers to discharge their duty by knowing the students strengths and other capabilities. Employability can be enhanced if the requirements from the industry are incorporated into the education system. This paper provides a detailed review on various Learning Analytics tools, applications and the techniques used to design and develop Learning Analytic systems.

\section{REFERENCES}

[1] Charles S.Elliott, " JACME2T: AN INDUSTRY ACADEMIC CONSORTIA TO ENHANCE CONTINUING ENGINEERING EDUCATION “, FIE Conference, 1998

[2] Khalid Isa, Shamsul Mohamad, ZarinaTukiran," Development of INPLANS: An Analysis on Students' Performance using Neuro-Fuzzy", symposium on information technology, vol 3, pages 1-7, 2008

[3] Tsolakidis Anastasios, Cleo Sgouropoulou, Ioannis Xydas, Olivier Terraz, Georgios Miaoulis,"Academic Research Policy-making and Evaluation using Graph Visualisation", Panhellenic conference on Informatics, 2011, pages 28-32

[4] Hsu-Chen Cheng, Wen-Wei Liao," ESTABLISHING AN LIFELONG LEARNING ENVIRONMENT USING IOT AND LEARNING ANALYTICS", ICACT, pages 1178-1183, 2012

[5] Israel Gutiérrez Rojas, Raquel M. Crespo García,"Towards efficient provision of feedback supported by learning analytics", ICALT, pages 599603, 2012

[6] Naif Radi Aljohani Hugh C. Davis, "Significance of Learning Analytics in Enhancing The Mobile and Pervasive Learning Environments ", NGMAST, pages 70-74, 2012

[7] Eleni Koulocheri Alexandros Soumplis Michalis Xenos, "Applying Learning Analytics in an Open Personal Learning Environment A quantitative approach", PCI, pages 290-295, 2012

[8] Ángel F. Agudo-Peregrina, Ángel Hernández-García, Santiago Iglesias-Pradas, "Predicting academic performance with learning analytics in virtual learning environments - A comparative study of three interaction classifications", SIIE, pages 1-6, 2012

[9] Carlos Márquez-Vera, Cristóbal Romero Morales, and Sebastián Ventura Soto, "Predicting School Failure and Dropout by Using Data Mining Techniques", IEEERITA, Vol 8, pages 7-14, 2013

[10] N. Pratheesh T. Devi, " Influence of Learning Analytics in Software Engineering education", ICE-CCN, pages 712-716,2013

[11] Carlos Delgado Kloos, Abelardo Pardo*, Pedro J. Muñoz-Merino, Israel Gutiérrez, Derick Leony, ' Learning Analytics @ UC3M”, EDUCON, pages 12321238,2013

[12] Gregorio Robles, Jesus M Gonzalez Barahona, "Mining student repositories to gain learning analytics - An Experience report", EDUCON, pages 1249-1254, 2013
[13] Muazzam Ahmed Siddiqui and Shehab Gemalel-Din, "Evaluation of Academic Plans of Study Using Data Mining Techniques", ICALT, pages 224-228, 2013

[14] Yohannes Kurniawan Erwin Halim, "Use Data Warehouse and Data Mining to Predict Student Academic Performance in Schools: A Case Study (Perspective Application and Benefits)", TALE, pages 98-103, 2013

[15] Naif Radi Aljohani Hugh C. Davis, "Learning Analytics and Formative Assessment to Provide Immediate Detailed Feedback Using a Student Centered Mobile Dashboard", NGMAST, pages 262-267, 2013

[16] Kannan Govindarajan, Thamarai Selvi Somasundaram, Vivekanandan S Kumar, Kinshuk, "Continuous Clustering in Big Data Learning Analytics", ICT4E(TECHNOLOGY FOR EDUCATION), pages 61-64,2013

[17] Ferreira S.A and Andrade A, "Academic Analytics: Mapping the Genome of the University", IEEE-RITA, Vol 9, issue 3, pages 98-105, 2014

[18] Juan Cruz-Benito, Roberto Therón, Francisco J. GarcíaPeñalvo Cristina Maderuelo, Jonás Samuel PérezBlanco, "Monitoring and feedback of Learning Processes in Virtual Worlds through analytics architectures: a real case", CISTI, pages 1-6, 2014

[19] George Lepouras, Akrivi Katifori, Costas Vassilakis, Angeliki Antoniou, Nikos Platis, "Towards a Learning Analytics Platform for Supporting the Educational Process", IISA, 2014

[20] Chatti M.A, Dugoija D, Thus H, Schroeder U, "Learner Modeling in Academic Networks", ICALT, pages 117 121,2014

[21] Luis de-la-Fuente-Valentín, Daniel Burgos, Rubén González Crespo, "A4Learning: a case study to improve the user performance Alumni Alike Activity Analytics to self-assess personal progress", ICALT, pages 360362,2014

[22] Sven MANSKE, Tobias HECKING, Lars BOLLEN, Tilman GÖHNERT, Alfredo RAMOS, H. Ulrich HOPPE, "A Flexible Framework for the Authoring of Reusable and Portable Learning Analytics Gadgets", ICALT, pages 254-258, 2014

[23] Manav Malhotra I-Han Hsiao Hui Soo Chae Gary Natriello, "Data Depository: Business \& Learning Analytics for Educational Web Applications", ICALT, pages 363-364, 2014

[24] Olga C. Santos Sergio Salmeron-Majadas Mar Saneiro Jesus G. Boticario, "A Methodological Approach to Eliciting Affective Educational Recommendations", ICALT, pages 529-533, 2014

[25] Carlotta Schatten, Martin Wistuba, Lars SchmidtThieme Sergio Gutierr'ez-Santos, "Minimal Invasive Integration of Learning Analytics Services in Intelligent Tutoring Systems”, ICALT, pages 746-748, 2014

[26] Sandra Gama, Daniel Goncalves, “Visualizing Large Quantities of Educational Data mining", Internationa Conference in Information Visualization(ICIV), pages 102-107, 2014 
[27] Hayriye Tugba Ozturk Deniz Deryakulu Huseyin Ozcinar Deniz Atal, "Advancing Learning Analytics in Online Learning Environments Through the Method of Sequential Analysis", International Conference on Multimedia Computing and Systems(ICMCS), pages 512-516, 2014
[28] Usamah bin Mat, Norlida Buniyamin, Pauziah Mohd Arsad, RosniAbu Kassim, "An Overview of Using Academic Analytics to Predict and Improve Students' Achievement: A Proposed Proactive Intelligent Intervention", IEEE Conference on Engineering Education (ICEED), pages 126-130, 2013 